\title{
A NEW 'RAY OF LIGHT' IN SOCIO-ECONOMIC RIGHTS JURISPRUDENCE? A NOTE ON COUGHLAN NO $V$ ROAD ACCIDENT FUND (CENTRE FOR CHILD LAW AMICUS CURIAE) (CCT160/14) [2015] ZACC 9
}

\author{
by Romy-Anne Templeton
}

\section{Introduction}

The justiciability of socio-economic rights in the South African courts has been the subject of much academic debate. This issue of justiciability spans back to the drafting of the final Constitution - the question at the time concerned whether or not these rights should be included in Chapter II of the Constitution. The fact that the justiciability of socio-economic rights has been an on-going concern for the last two decades illuminates the difficulties faced by the courts in giving substantive content to these rights. The courts often respond to these situations by way of deference. ${ }^{1}$ Brand defines deference as 'a strategy of the courts, when faced with difficult, technical or contested social questions...to leave the decision of those issues in different ways and to varying degrees, to the other branches of government. 2 The judgment of Coughlan NO v Road Accident Fund (Centre for Child Law Amicus Curiae) (CCT160/14) [2015] ZACC 9 is arguably described as a ray of light amongst the dark clouds that normally shroud socio-economic rights jurisprudence. The discussion on the judgment will comment on the decision with reference to the following issues:

- The clarification of the relationship between the general socioeconomic right to social assistance and the right related to children;

- The distinction between foster child grants and a damages award;

- The extension of the principle to child support grants; and

- The justiciability of the child's right to social assistance.

* $\quad$ Final year LLM, University of Pretoria, BA LLB, Rhodes University.

1 D Davis 'To defer and then when? Administrative law and constitutional democracy' (2006) Acta Juridica 23.

2 D Brand 'Judicial deference and democracy in socio-economic rights cases in South Africa' (2011) 22.3 Stellenbosch Law Review 614. 


\section{Factual background}

The plaintiff, one Coughlan, brought the application in his representative capacity as curator ad litem to claim damages in respect of past and future loss of support on behalf of three children. ${ }^{3}$ The children were maintained solely by their mother, Ms Beyers, as their father had predeceased their mother. ${ }^{4}$ Their mother was subsequently killed in a road accident in June 2002. ${ }^{5}$ The issue before the High Court was whether the grants had to be deducted from the damages. ${ }^{6}$ The High Court, as per Henney J, held that the grants did not need to be deducted as they constituted res inter alios acta. ${ }^{7}$ The RAF appealed against the decision in the Supreme Court of Appeal which, per Lewis JA, reversed the decision of the High Court. It reasoned that but for the death of Ms Beyers, the grants would not have been claimed. ${ }^{8}$ It continued to say that the award of damages in addition to the grants amounted to double compensation which was impermissible. ${ }^{9}$ It therefore upheld the RAF's appeal. ${ }^{10}$ Coughlan appealed against the decision of the Supreme Court of Appeal in the Constitutional Court. ${ }^{11}$

\section{The decision}

The High Court had to decide whether the foster child grants were to be deducted from the amount agreed upon for loss of support or whether the social grant payments were classified as res inter alios acta and therefore not deductible. ${ }^{12}$ The curator's contentions were twofold. Firstly, he contended that the social grant payments were res inter alios acta and therefore not deductible because they were paid to people who elect to become foster parents. ${ }^{13}$ Payments are not made directly to the children. The curator relied on Makhuvela $v$ Road Accident Fund 20101 SA 29 (GSJ) ${ }^{14}$ where the High Court held that social grant payments are necessary to realise the constitutional rights of the child - payment is made to the foster parents who aid in the realisation of these constitutional rights. The curator's second contention was premised on establishing how to determine whether (CCT160/14) [2015] ZACC 9 at para 2.

4 Coughlan (n 3 above) para 7.

As above.

Coughlan (n 3 above) para 10

Coughlan (n 3 above) para 16.

Coughlan (n 3 above) para 19.

As above.

1 As above.

1 Coughlan (n 3 above) para 21.

Coughlan (n 3 above) para 10.

13 Coughlan (n 3 above) para 11.

14 Makhuvela v Road Accident Fund 20101 SA 29 (GSJ) paras 8-9. 
the payments were deductible. ${ }^{15}$ He relied on Zysset \& Others $V$ Santam Limited 19961 SA 273 (C) which held that the enquiry concerned two conflicting public policy considerations: the dependent should not receive double compensation yet the wrongdoer should not be relieved of his liability. The RAF submitted that if double compensation resulted it would be at the expense of taxpayers. This is because the foster care grants and the RAF funding are both pooled from the National Treasury. ${ }^{16}$ The RAF relied on Road Accident Fund v Timis [2010] ZASCA 30 which held that it was not the purpose of the legislation to permit double compensation, and thus social grants were deducted from the RAF damages award. The High Court rejected the RAF's reliance on Timis owing to the fact that it concerned child care grants and not foster child grants. ${ }^{17}$ It further held that death of Ms Beyers merely formalised the guardianship that Ms Beyers' parents had over her children as the children were already in their care before Ms Beyers' death. ${ }^{18}$ The RAF was ordered to make payments accordingly.

In the Supreme Court of Appeal, the RAF argued that the High Court had incorrectly relied on Makhuvela and thus urged the Supreme Court of Appeal to place reliance on the judgment handed down in Timis and therefore extend its reasoning to foster child grants. ${ }^{19}$ The Supreme Court upheld the appeal on the ground that there was no difference in substance between child care grants and foster child grants. ${ }^{20}$ It noted that no evidence was produced to indicate that Ms Beyers' parents needed additional funds for the support of the children after the death of their mother. ${ }^{21}$ It also submitted but for Ms Beyer's death, her parents would not have claimed foster child grants. The Supreme Court subsequently set aside the decision of the High Court. ${ }^{22}$

\section{The relationship between the general right to social assistance and its relation to children}

The Court looked at the relationship between the general right to social assistance set out in section 27(1)(c) of the Constitution and its relation to the constitutional rights of children set out in section 28 of the Constitution. 
The state, in terms of section 27(2) of the Constitution, has an obligation to take legislative and other measures to realise the general constitutional right of social assistance. Because the issue concerned the welfare of children, the Court was obliged to read section 27(1)(c) with the relevant provisions set out in section 28 of the Constitution. The relevant sections were sections 28(1)(b), (c), (d) and (2). The Court placed reliance on the dicta in Government of the Republic of South Africa and Others V Grootboom and Others 2001 1 SA 46 (CC) ${ }^{23}$ which held that sections $28(1)(\mathrm{b})$ and (c) underscore the child's need for care. The Court observed that the state had enacted three pieces of legislation to give effect to these section 27 and 28 constitutional rights. ${ }^{24}$ These are namely the Children's Act, ${ }^{25}$ the Child Care Amendment Act ${ }^{26}$ and the Social Assistance Act. ${ }^{27}$

Section 156(1)(e) of the Children's Act was analysed by the Court. This section lists different options of care from which the Children's Court can choose if it finds that a child's current standard of care, or lack thereof, is seriously wanting. In respect of the matter before it, the Court observed that foster care was a means of care listed in section 156(1)(e). ${ }^{28}$ The Court contrasted the situation where a child is placed in foster care with one where the child is relocated to a youth centre. ${ }^{29}$ The enquiry that followed was whether the expense that the state incurred by caring for the child in one of its youth centres should be deducted from a damages award made by the RAF? ${ }^{30}$ The Court concluded that it would amount to unreasonable differentiation between children placed in foster care and those residing in youth care centres. ${ }^{31}$

\section{The distinction between a damages award and foster child grants}

The Court highlighted the difference between foster care grants and damages for loss of support. ${ }^{32}$ The difference between the two lies in the content that the Court prescribed to each. This was accomplished by looking at the difference between 'care' in terms of the Children's Act and 'compensation' in terms of the Road Accident Fund Act. According to the Children's Act, 'care', in relation to a child, encompasses a multiplicity of aspects all closely associated with the

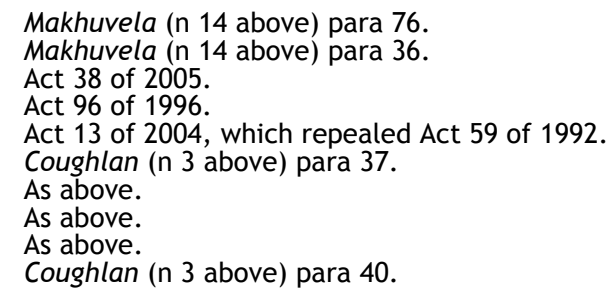


provision of suitable accommodation, appropriate living conditions that promote the child's well-being as well as the necessary financial support. ${ }^{33}$ It then considered the purposes of foster care in terms of section 181 of the Children's Act which underscored the need to provide children with a supportive and nurturing family environment. ${ }^{34}$ The Court gave relatively substantive content to what 'foster care' entails and that foster care 'is expansive and extends beyond mere money and encompasses parenting, love, care, nurturing, discipline and other benefits of raising a child in a family environment. ${ }^{35}$ Foster care, as per the Children's Act attempts to place the child in a family set up that seeks to provide them with the many benefits that accrue to family life. ${ }^{36}$ This is contrasted with an award of damages which is not calculated on the basis of care. ${ }^{37} \mathrm{~A}$ damages award is intended to be compensatory to the extent that it wishes to reimburse the child for loss related to his material needs.

It then looked at the monetary and non-monetary components of 'care' and 'compensation'. Reference was made to the case of Jooste $\checkmark$ Botha 20002 SA $199(T)^{38}$ which decidedly held that the parent-child relationship is twofold. There is a psychological aspect, which is classified as a non-monetary component, as well as an economic aspect. The non-monetary components of 'care' have already been abovementioned. The Court noted that although material needs can be 'adequately compensated' by a monetary award, the same cannot be said for the loss of parental care. ${ }^{39}$ On this premise it ruled that an award for damages for the loss of support cannot replace the purposes for which foster parenting is permitted. ${ }^{40}$

Finally, it considered who the payments were made to. According to the Regulations for the Social Assistance Act, grants are paid to foster parents if they meet the eligibility requirements. ${ }^{41}$ The grant forms part of the foster parent's patrimony and must be spent according to the best interests of the child. The Court relied on the dictum in Makhuvela which held that '[the] primary purpose [of the grant] is the realisation of constitutional rights of the child through foster parent intervention. ${ }^{, 42}$ In contrast, RAF payments are made directly to the child to replace the income upon which they would have survived but for the death of the parent caused by a motor vehicle accident. ${ }^{43}$

33 Coughlan (n 3 above) paras 38-39.

34 Coughlan (n 3 above) para 40.

35 As above.

36 As above.

37 Coughlan (n 3 above) para 41.

38 Jooste $v$ Botha 20002 SA 199 (T) 201E-F.

39 Coughlan (n 3 above) para 44.

40 As above.

41 Coughlan (n 3 above) para 45

42 Makhuvela (n 14 above) paras 8-9.

43 Coughlan (n 3 above) para 46. 
In sum, the Court illuminated that there is a difference between the nature and purpose of social grants and that of compensatory payments. The purpose of the social grants is directly related to the constitutional obligation placed upon the state to provide for children in need of care. ${ }^{44}$ In light of this finding, the Court established that there was no double compensation and therefore it was not required to establish whether or not the payments were res inter alios acta. ${ }^{45}$

\section{Extending the principle}

One of the most important and most interesting aspects of this judgment is that the Court overturned a decision that was not argued before it. The Centre for Child Law requested the Court to consider extending the principle concerning the deductibility of foster child grants from a damages award to child support grants. ${ }^{46}$ The Court underscored that the importance of this decision was one of public importance especially in light of the constitutional obligation of the state to come to the aid of vulnerable people and children. ${ }^{47}$ It was mentioned that the only distinguishing feature between foster child grants and child support grants is the application of the means test to determine the eligibility of primary care givers for child support grants. ${ }^{48}$ Child support grants can only be claimed if the primary care giver(s) earns an income below the established threshold. Foster child grants are awarded irrespective of the foster parent's level of income. The Court looked at the nature and purpose of the two social assistance grants and held that they are both predicated on the realisation and achievement of care of the child. ${ }^{49}$ In its decision to reject the finding made in Timis, the Court reasoned that the judgment failed to acknowledge that the state plays very different roles when it makes the payments. ${ }^{50}$ On the one hand the state acts as a caregiver when it makes social grant payments. On the other hand, the state assumes the role of the wrongdoer when it makes RAF payments. ${ }^{51}$ The Court finally examines the RAF Act and accordingly observes that if the RAF Act intended for double payment to be avoided (as is the position payments made in terms of the Compensation for Occupation Injuries and Disease Act) ${ }^{52}$ then the RAF Act would have expressly acknowledged this.

\footnotetext{
4 Coughlan (n 3 above) para 51.

As above.

Coughlan (n 3 above) para 54.

Coughlan (n 3 above) para 53.

Coughlan (n 3 above) para 55.

4 As above.

50 Coughlan (n 3 above) para 57.

51 As above.

52 Act 130 of 1993.
} 


\section{The justiciability of the right to social assistance}

Another noteworthy aspect of this decision is founded in the way the Court employed reasonableness review to adjudicate the matter. In spite of the fact that the rights issue before the Court was very narrow this judgment makes a contribution towards socio-economic rights jurisprudence. The Introduction hinted that the justiciability of socioeconomic rights is fraught by a complex matrix of enquiries and subsidiary issues which the courts elect not to properly adjudicate upon. One of the strategies that the courts employ to skirt around deciding these issues is judicial deference. Although deference can manifest itself in numerous ways, a discussion on these variations detracts from the focus of this note. It is proposed that the standard of review imposed by reasonableness was utilised by the Court in a manner that resulted in popular support for the outcome.

Price defines reasonableness as 'an act ... in everyday life.' 53 Essentially, the RAF, an organ of state, sought a judicial pronouncement that would effectively deprive children of their right to social assistance. In assessing the reasonableness of the RAF's request regard must have been had to 'an evaluation of competing considerations, costs and benefits, likely consequences and side effects, and a decision, on balance, that the 'reasons for' defeat the 'reasons against'. ${ }^{54}$ It is argued that the Court engaged fully with this process which resulted in an outcome favourable to socio-economic rights jurisprudence. To that end, and upon request by the Centre for Human Rights, it extended the ruling so that it would apply to child support grants.

\section{Conclusion}

The judgment of Coughlan is hailed for two important reasons. The first is explained in the following terms: the Court decided a matter before by employing reasonableness review, an arguably deferential structure of review that concerns itself with processes instead of demarcating the substantive content that should accrue to rights. Within the framework of reasonableness review, the Court decided the matter in favour of Coughlan, and subsequently in the esteem of socio-economic rights jurisprudence. Regard was had to the numerous competing considerations between the RAF and Coughlan. The RAF ultimately sought to restrict the child's right to social assistance and 
this was unreasonable, and unjustifiable. Regard was also had to the constitutional obligations of the state to protect children and have their rights to care and social assistance realised. For numerous reasons, and in light of public policy considerations, the Court held that to deduct the foster child grants from an award for damages would be unreasonable. Furthermore, it stood, unequivocally, against the purpose of the RAF Act which was 'to give the greatest possible protection to claimants'. ${ }^{55}$ The second important aspect of this case was the fact that the Court overturned a decision of the Supreme Court of Appeal that was not an issue before it. This stands in stark contrast to the deferential stance that the courts normally assume in socio-economic rights cases where it fears encroaching upon the domains of the Legislature and the Executive. For this reason, this judgment is a feat for socio-economic rights jurisprudence, albeit a small one, because the Court sought to aggressively defend the child's right to social assistance. 